\title{
Haiti: An Ethnographic Study of the Effects of International Aid on Haitian Life
}

Wai Chung Tse, Monash University School of Medicine

Lamia Makkar, Haiti: Hands On, Haiti

\section{Abstract}

Haiti has seen an increasing number of non-governmental organisations (NGOs) and intergovernmental organisations (IGOs) providing structural and emergency aid in times of conflict and natural disasters (Laillet, 2020). This was intensified in 2010 when Haiti regained international attention from a ravaging earthquake that shook its core. This ethnographic study analyses the effects of NGOs and IGOs a decade after this natural disaster. We attempt to venture beyond the statistical evidence grounding most analyses provided by NGOs and IGOs to reveal perspectives from individual Haitians who have been impacted by the policies and decisions of these organisations. In doing so, we examine the local standard of living, the infrastructure and the social dynamics through four in-person interviews conducted in their respective geographic locations. These interviews set a basis for a discussion and examination of organisations' allocation, dependency on the organisation and the sustainability of an action once an organisation has decreased its input. The voices of local Haitians reveal that the profound yet subtle impacts under-represented in narratives are crucial to understanding the day-to-day challenges faced despite foreign aid. We conclude that Haitians face a stasis of social mobility, despite the copious work done by aid organisations that is often inconsistent and misaligned with the needs of Haitians.

Keywords: Haiti, foreign aid, sustainability, non-governmental organisations (NGO), intergovernmental organisations (IGO), ethnography

\section{Introduction}

In times of crisis, non-governmental organisations (NGOs) and intergovernmental organisations (IGOs) are a critical foundation for relief efforts. For Haiti - a Caribbean country with an intricate past - NGOs and IGOs have played a key role in the nation's recent history. Before the 2010 earthquake, the UN conservatively estimated that there 
were already up to 10,000 NGOs established in the country (Edmonds, 2013: 2), earning the country the moniker the 'Republic of NGOs' (Farmer, 2011: 4). Since then, the number of organisations has surged - particularly following the 2010 earthquake, which killed an estimated 220,000 people and displaced another 1.5 million (UN Peacekeeping, 2018). Although considered 'the worst national disaster in the history of the Western hemisphere' (Birrell, 2012), this event gave Haiti the rare opportunity to rebuild and transform itself. The impressive international response to the earthquake saw over $\$ 2$ billion donated to charities and another $\$ 6$ billion pledged by governments and institutions (Birrell, 2012). However, despite the expectations from international bodies and Haitians alike that organisations would provide relief and stability for Haiti, the presence of NGOs and IGOs has instead aggravated violence, sexual assault and wealth disparity within the nation (Beeton, 2012). Following the earthquake, 'the dysfunctional system of humanitarian aid ... good intentions aside, has become another obstacle to Haiti's recovery and sovereignty' (Farmer, 2011:4). Haiti remains in stasis, seemingly unable to escape from the rubble it found itself in a decade ago. This incongruity between expectation and reality of foreign intervention highlights the severe effects that organisations have had on Haitian life.

\section{Historical context}

Throughout the late twentieth century, when Haiti's leadership changed frequently in part by the hand of US interventions - political and social life was left unstable and vulnerable. Consequently, Haitian agricultural industries - the cornerstone of the Haitian economy - were unsupported by the government and became especially vulnerable to foreign actors. When the incumbent president-deemed-dictator Jean Claude 'Baby Doc’ Duvalier was exiled and replaced by General Henri Namphy’s military rule, the International Monetary Fund (IMF) pressured Namphy to cut rice tariffs that protected the local agricultural industry. The competition between foreign imports with heavy subsidies and local produce hindered local farmers, resulting in a significant diminishment of the agricultural workforce as they moved to cities in search of income (Kushner, 2012).

This large influx of a formally rural population, coupled with unemployment and Haiti's political instability, led to the coup d'état of Jean-Bertrand Aristide in 2004. However, given the copious resources in Haiti owned by the American government and nationals, instability in Haiti was unacceptable for US interests. This instigated the intervention of the UN Peacekeeping Force in Haiti, (MINUSTAH) under the premise of 
maintaining peace and security, which was later dissolved and replaced with the United Nations Mission for Justice Support in Haiti (MINUJUSTH) in 2018 (United Nations Security Council, 2018). Before Haiti had a chance to salvage its economy and restructure its leadership, the 20107.0 magnitude earthquake devastated the country. Instability within the Haitian government, coupled with a lack of agricultural produce, rendered the nation unsustainable on its own and perpetuated recurring international intervention (Panchang, 2016).

\section{Rationale for foreign intervention}

Although the Haitian government is arguably more stable and structured now compared to 2004, internal corruption remains (Moreno et al., 2012). Haiti additionally continues to be confronted by challenges, including over-population in the capital, Port-au-Prince, and violence incited by urban poverty and high unemployment (Congressional Research Service 2020; Justesen and Verner 2007; Marcelin, 2015). Although foreign governments are often a prominent source of funding for aid organisations, many find developing governments such as Haiti's to be frequently corrupt. As such, the funds pledged to aid the people rarely end up in the hands of those who need it; instead, they were never delivered, mismanaged by foreign organisations or used by government officials for extravagant lifestyles disproportionate to the commonwealth (Moreno et al., 2012). With the redirection of funding towards aid organisations, there lacks a united coordination to direct funding and aid towards priority areas requested by local need (Laillet, 2020).

Following the earthquake, large foreign aid organisations provided immediate relief to locals in the form of emergency aid such as food, water and shelter. For the purposes of this paper, the term 'foreign aid' is used to describe the large international humanitarian relief organisations focused on aid in post-disaster (environmental, human, political and other) contexts. Although some of the stated challenges exist in local, grass-roots, bottom-up and structural development organisations and projects, the discussion of these is beyond the scope of this study, given their key features and methods that differentiate them from large international relief NGOs and IGOs. While emergency aid is crucial to survival in times of humanitarian crisis, they are often unsustainable, and their persistence beyond times of crisis creates dependency (Beeton, 2012; Birrell, 2012). The transition from urgent emergency aid to longer-term development, however, has not been clear in Haiti, with many foreign aid organisations persisting beyond the immediate crisis and attempting to take on the 
Reinvention: an International Journal of Undergraduate Research 14:1 (2021) role of development organisations and government bodies. This ineffective planning and impractical execution results in minimal development, while also creating new threats to the Haitian people (The Lancet, 2016). Consequently, not only are many foreign aid organisations funded to continue unsustainable aid but also projects that are sustainable fall short of their expectations due to poor planning and management, and a top-down approach that does not recognise and address the needs of the supposed beneficiaries. This revelation within academic communities has led to scholarly research focused on the intent and effects of aid organisations in Haiti.

\section{Intent and effects of aid}

Scholars, including Beeton and Panchang, are sceptical of the intent of aid organisations in the country. Haiti has become extremely dependent on international organisations - most notably peacekeeping groups, organisations distributing food and water, and public health groups - as they provide services that its own government cannot (Pilinger et al., 2016). When these organisations depart, they leave behind gaps of basic needs that the government is unequipped to fill. This large dependency on organisations thus creates an unequal power dynamic between the government and aid organisations, allowing the latter to have seemingly free rein in Haiti and ostensibly having the power to execute its own agenda on a foreign state. It is commonly known within local development circles that the large majority of international organisations operating in Haiti are not registered locally, which further limits oversight and cooperation between the government and aid organisations. Beeton (2012) even claims that organisations such as the UN are there for their own gain, profiting off Haiti’s misfortune. Despite MINUSTAH's large budget of \$1 billion per year (United Nations Security Council, 2017), most of its resources are spent maintaining its peacekeeping force. Further, money devoted to aid organisations is often not reinvested into the Haitian economy to create jobs and infrastructure. Instead, resources like MINUSTAH's are often spent hiring foreign staff and importing vehicles to Haiti and projects requiring construction are led by foreign companies with minimum wage jobs given to local Haitians (Panchang, 2016). These socio-economic hierarchies reveal why Haiti is so profitable for aid organisations, as they attempt to bolster their own country's economies (Beeton, 2012).

\section{Limitations of current research}


Reinvention: an International Journal of Undergraduate Research 14:1 (2021)

While there are numerous NGOs and IGOs operating in Haiti, research thus far has primarily centred around the ineffective structures and effects of the UN's intervention through observational and statistical analyses (Beeton, 2012; James, 2010; Panchang, 2016; The Lancet, 2006; The Lancet, 2016).

Accurate evidence of the inefficacy of international organisations has been difficult to attain as language barriers, power dynamics and scholar bias hinder data collection. James (2010) reveals the challenges faced during data collection with Haitians who faced mental and physical trauma, including falsified accounts. The exchange of personal narratives from Haitians for aid has driven both organisations and Haitians to misrepresent reality, highlighting the disproportionate power dynamics in aid that manifest in a coercion of the recipients' voices.

Panchang (2016) echoes this sentiment through his criticism of the 2010 cholera outbreak being blamed on Haitians, despite copious evidence showing that Nepalese UN peacekeepers caused the outbreak at their Mirebalais base (Chin et al. 2011). The media commonly depicts Haitians as unable to maintain sanitary and healthy living environments. This inaccurate depiction presents a façade to the international community of Haiti's helplessness without international intervention and, in turn, further perpetuates the justification for continued aid efforts.

Scholars have also turned to statistical data in hopes of minimising subjectivity and scholarly bias, involving quantitative analysis focusing on the criticism of large, wellknown organisations such as the UN (Beeton, 2012; The Lancet, 2006; The Lancet, 2016). However, beyond statistical data, unreported accounts may go unexplained or without context, resulting in the misattribution of blame towards social phenomena and groups.

Consequently, we investigate the effects of non-UN international aid on Haitians in both rural and urban settings with a focus on portraying the challenges and realities faced by Haitians in both contexts.

\section{Methodology}

Data was collected through semi-structured interviews and observational research. This study was conducted as an ethnography, given the pressing need to add local experiences to the larger discussion of the efficacy of international aid and to supplement the current statistical data that makes up the majority of current 
Reinvention: an International Journal of Undergraduate Research 14:1 (2021)

evaluations of Haitian aid. By centring Haitian voices, this study aims to highlight the effects of foreign aid on Haitian life.

Through the contacts and network of a local organisation, Haiti: Hands On, we travelled to different disadvantaged communities in Port-au-Prince and two rural villages, Terre Froide and Jean Jean (Figure 1). We interviewed community representatives of their own communities and used convenience sampling through contacts in the Haiti: Hands On network. The former is near Fonds-Verrettes and the latter near Léogâne, both of which are located in the south-east and south-west of Port-au-Prince, respectively. In Terre Froide, we interviewed a family and observed them in their daily lives as well as visited two schools and one clinic in surrounding communities. Although participant observation was conducted in Jean Jean, an unexpected community accident prevented us from being able to complete our planned interviews.

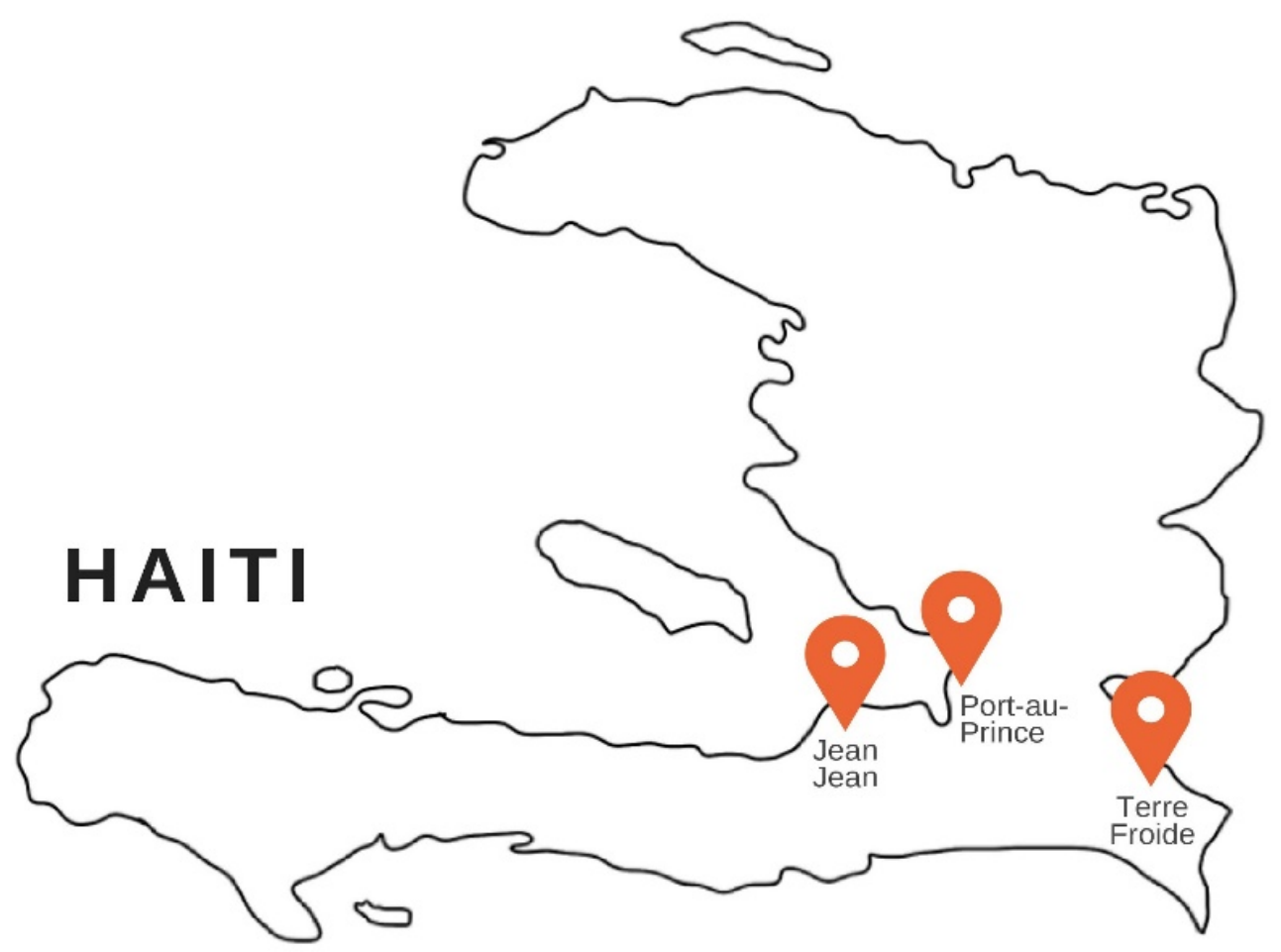

Figure 1: Map of interview sites in Haiti.

Our observations and interviews in urban settings centred around the greater Port-auPrince area, including wealthy areas such as Pétion-Ville and less developed areas such as Canapé Vert and Croix-des-Bouquets. In all, we interviewed a housekeeper in Pétion-Ville, two members of the Terre Froide community and a Haitian NGO worker 
Reinvention: an International Journal of Undergraduate Research 14:1 (2021)

in Canapé Vert, all ranging in age and gender. All four interviews were conducted in Creole with the presence of a translator and notes transcribed by summary. Our observations included those from different areas and informal conversations exchanged between Haitians, NGO workers and foreign travellers. This study is inkeeping with the American Anthropological Association code of ethics and approved by Haiti: Hands On. Verbal, informed consent for interviews was obtained in Creole. The interviewees' names were deidentified for confidentiality purposes.

\section{Discussion}

Impacts of aid organisations on Haitian Life

\section{Who gets what?}

In times of natural disasters and conflict-related emergencies, communities without adequate infrastructure and support systems are left most vulnerable. These impacts are especially pronounced in Haiti, where many communities are isolated geographically with poor infrastructure. Chedeline - a housekeeper working in PétionVille - grew up in Jérémie, a rural community near the south of Haiti and moved to the capital 15 years ago in search of opportunities better than agricultural work. When Hurricane Matthew struck in 2016, impacting mainly the Southern part of Haiti, her parents' house and agricultural produce in Jérémie were destroyed. Chedeline's parents became dependent on her income in the capital to support them.

Despite Hurricane Matthew's ravaging impact on communities such as Jérémie in the south of Haiti, Chedeline does not recall any international aid being offered to her parents' community. She recounted that, after the hurricane, roads connecting to the south of Haiti became inaccessible and hazardous. As a result, aid organisations instead focused on the more easily accessible communities, despite being less impacted. However, since it was paramount for Chedeline to provide safe shelter for her parents regardless of whether aid to Jérémie was available, she not only had to purchase materials to rebuild their house, but also pay for transportation to move materials from the capital to their community. This situation indicates a discrepancy of aid distribution based on geographic accessibility, regardless of the level of impact.

There are communities in Haiti that have been aided by NGOs in times of humanitarian crisis. In Terre Froide, a rural community in the east, we interviewed Emmanuel, a farmer who has lived in the community since 1984 . He recounted the 
Reinvention: an International Journal of Undergraduate Research 14:1 (2021) times his community was afflicted by natural disasters. In times of drought, like the spell from 2011 to 2015, an NGO came to their aid and occasionally - yet inconsistently - provided water for their crops and animals. Even though Terre Froide did receive aid, its erratic delivery did not provide the community with the resources to recover fully.

The issues presented by Chedeline and Emmanuel highlight the lack of consistent aid outside the capital, where many aid organisations have been concentrated since 2010 (Beeton, 2012). The vast presence of aid and funding within Haiti should suggest that aid should arrive in places of need at a duly time, thus highlighting problems lying not in resources or funding, but in the delivery of aid. However, many NGOs and IGOs present in Haiti are developmental and have limited capacity for providing emergency aid to communities in times of crisis. That being said, the uncertain presence of such aid in communities beyond the capital remains concerning for emergency or developmental aid.

Food, shelter and water are basic necessities. In Chedeline's case, the dangerous roads, which were damaged by the hurricane, did not impede her from finding a way to provide these necessities for her parents. The irony is that the work promised by aid organisations - the entire reason they are in Haiti in the first place - often falls in the hands of already vulnerable family members who are placed in even more precarious situations by virtue of helping. This highlights the false promises made to Haitians by these organisations by their very presence in the country. As many such crises result in the loss of life, or leave even those with comparative means, like Chedeline, unable to support their families, the reliance on immediate or extended family thus becomes impossible.

This failure by organisations to provide aid to Jérémie, despite their significant funding, underlines The Lancet Global Health's criticism (2016) on the ineffectiveness of aid organisations in providing Haitians with adequate and timely support during humanitarian crises. However, this disparity of aid not only suggests that NGOs decide aid based on a community's accessibility, but also implies that the intent of certain aid organisations may be to provide aid that is most economical and efficient for the organisation. This further corroborates Beeton's suggestion that these international organisations are using funds to further their own organisational and national economies (Beeton, 2012), and they are sustaining their presence by selectively choosing economical and accessible communities to show donors that they are, in fact, doing meaningful work in Haiti. 
Although aid organisations have been present in Terre Froide, Emmanuel noted that most would be inconsistent and would never stay for long periods of time for continued support of the issues they faced. While aid organisations have supplied water for farmers like Emmanuel in times of drought, it takes upwards of a decade for these rivers to return to their original ability to provide water to entire communities. However, as soon as rainfall restarted in 2015, the organisations previously providing support with water access discontinued their aid. As a result, Emmanuel's family now has to travel about 1 hour by foot in order to find sufficient water for their crops.

Kervens, another member of the Terre Froide community, echoes this sentiment by describing the times in which the NGOs working in neighbouring regions would spontaneously appear and disappear over the span of two to three years. A health clinic 30 minutes away from Terre Froide that was once opened by the UN, and provided healthcare for the surrounding communities, was operational for three years until it closed. We got in touch with the mayor there and travelled to the closed health clinic to find the building still operational, but no longer run by the UN. Instead, a small NGO uses this clinic as a malnutrition centre to distribute dietary supplements for malnourished children. The mayor explained that the clinic - originally staffed by doctors and nurses who provided care to the area - closed due to a re-prioritisation of funding. Now, people have to travel an hour by car to get health care, something that is not accessible for most families in Terre Froide. These trends that depict the scarcity and inconsistencies of international aid are discussed in the research of Beeton (2012), Pilinger et al. (2016), Panchang (2016) and The Lancet (2006), and suggest that the strategies adopted by aid organisations hinder their commitments towards communities beyond intermittent intervals.

Similar to Emmanuel and Kervens's daily challenges in Terre Froide, urban communities also have volatile relationships with aid organisations. In Port-au-Prince, we interviewed Robenson, a Haitian who does non-profit work in the capital's most disadvantaged areas. Robenson grew up in a squalid urban community built in the hills surrounding Port-au-Prince. He recounted that when there were large rainfalls, his area had to evacuate due to severe flooding. He noted that this instability within marginalised and deprived urban communities has worsened given the large influx of people from the rural areas in search of job opportunities and the relocation from neighbourhoods destroyed by the earthquake - the infrastructure of Port-au-Prince is unable to support a population of 2.6 million people. 
Reinvention: an International Journal of Undergraduate Research 14:1 (2021) While these natural disasters have caused significant infrastructural damage to Haiti, the most prominent effects have been due to the lack of education, health and nourishment. This slow erosion of wellbeing suggests that there is an underlying problem compounded by the social structures within Haiti that significantly impacts the quotidian life of Haitians. In all three of these cases (Emmanuel, Kervens and Robenson), little has been done to aid in the daily life of Haitians - despite many large NGOs and IGOs claiming to focus on these factors. Further, those that are involved in this work are often present for short periods of time - with an interventionist, topdown approach - giving communities a false sense of stability.

\section{Why is aid so arbitrary?}

In addition to being the founder of a Haitian non-profit organisation, Robenson worked for both the Haitian government and large foreign aid organisations. When asked about his experiences working with the latter, he stated that organisations in Haiti often have their own agendas that are contrary to the interests of Haiti. This begs the question of whether these aid organisations are there for Haitians or for their own benefit, supporting Pilinger et al.'s (2016) claim that international organisations are profiting from human suffering. Sharing Kervens's perspective in Terre Froide, Robenson noted that international aid projects often exhaust their funding after two to three years. He stated that aid organisations aim to create as many aid projects as possible in order to attract funding from large donors by demonstrating impact through statistics - an inaccurate measure of impact. Robenson noted that it is rare for large organisations to have reports of the lasting impacts on the community, corroborating our observations in the closed UN clinic in Terre Froide after operating for 3 years. This emphasis on superficial results and reductionism trickles down into the implementation of projects. Drawing upon the culture of superficiality in aid work, according to Robenson's experience as a field officer, the people on the front lines implementing change are discouraged from being receptive to feedback from communities. Instead, they are encouraged to report conflated results to align their reports with the consensus of people higher up in the organisation who have never been present in those same communities.

The emphasis on statistical representation within aid organisations has turned to value aid through quantity over quality. While The Lancet (2016) critiques the structure of aid organisations, it does little to elucidate the negative culture rampant within them. Robenson's observations while working in multiple aid organisations show that it is not only the ineffective bureaucracy but also the focus on providing 

statistical representation that reduces and categorises aid's impact on Haitians. This results in false hope, complacency and dependency that ultimately harms Haitians in their ability to escape the daily challenges that persist beyond the initial impact of the crisis. Little has been done regarding improving the quality of aid by large foreign organisations, some of which are implicated through the interactions with interviewees.

\section{Dependency.}

The dependency on foreign organisations for basic necessities - such as Doctors Without Borders and Partners in Health for free emergency healthcare - explains why the government has so little control over aid organisation work within Haiti. Organisations consequently are able to perpetuate systems of high-quantity, lowquality projects to Haitians. Like the government's dependency on aid organisations to provide basic services, communities have often developed a similar dependency.

Furthermore, the act of foreign intervention often shapes a Haitian image of foreigners, namely of the French, Americans and Canadians, as one rooted in aid. Coupled with the sole appearance of foreigners in the context of providing aid to the community, Haitians in rural communities often associate foreigners with help and thus expect it from those that interact with them. The negative experiences with aid described throughout this piece, coupled with the country's historical legacy of foreign colonisation, exploitation and violence by France, the United States and Western bodies such as the IMF have commonly, and understandably, resulted in a deeply rooted distrust towards foreigners and their intentions.

The manipulation of research through falsified accounts of Haitians who were sexually assaulted, as proposed by James's research, helps clarify the effects of continual interaction with foreigners under the context of aid and disproportionate power dynamics that result in misreporting of narratives (James, 2010). The Haitians interviewed for this study were aware of the actions needed to gain sympathy and support from foreigners. When projects fail and aid workers leave, it not only leaves behind empty buildings, disappointment and broken promises, but also perpetuates a distrust between communities and foreigners. This repetitious cycle of aid groups providing ineffective aid thus drives Haitians to make the most out of the duration of the project. While some Haitians are able to benefit in doing so, they are still unable to escape from the grasp of poor aid.

Sustainable aid through education 

Given these pitfalls of international aid, certain local grass-roots projects like Robenson's and smaller bottom-up foreign organisations, have effectively addressed community needs through a community-based, bottom-up approach that centres the voices of those most affected by systemic issues. However, Robenson recounted that it is hard to find both people willing to work for small NGOs and donors willing to fund small projects without the same recognition as large foreign organisations.

The consistent failure of large international NGOs in Haiti over the course of a decade may explain why Chedeline, Emmanuel and Kervens - living in both urban and rural communities - state that they perceive little to nothing having changed within Haiti since the influx of aid organisations after the earthquake. Instead, they have emphasised trying to only rely on themselves and their own communities since aid is often transient and ineffective when most needed. This realisation has instigated a call for change in status quo, with education as a possible vehicle.

\section{Why_education?}

All interviewees expressed that education is key to improving their own lives and Haiti's social discourse. Emmanuel, who works as a farmer and seamster, repeatedly emphasised that he does not want his children to follow in his footsteps. As a rural farmer, he is not only dependent on the climate of Haiti to nourish his crops but also on an economy that has consistently disadvantaged him. Emmanuel hopes his children will be able to escape this system that continues to deprive him by becoming doctors and teachers. He insinuated that he wants stability for his children, as well as safety from their being marginalised, and that their education could achieve that. When asked what it meant to be Haitian, his immediate response was the importance of education and perseverance. Since education is not free in Haiti, families have to pay exorbitant prices in order to educate all of their children (Beeton, 2012). In fact, the World Bank estimates that 80 per cent of schools in Haiti are privately owned or run by churches or NGOs (The World Bank, 2017). In Emmanuel's case, he has to pay for seven children to attend school. He hopes to send at least one of his children to university.

Chedeline's experiences have also taught her the importance of education. Growing up in Jérémie, she found that women did not have much choice other than to work in the fields and have a family. Instead, she aspired to be her own boss and create her own company. When she moved to Port-au-Prince in search of opportunities, however, she found that her primary education from Jérémie made it hard for her to find jobs and 
Reinvention: an International Journal of Undergraduate Research 14:1 (2021) opportunities that supported her aspirations. As a result, she went to culinary school and became a private chef and housekeeper for a wealthy Haitian-American family in Pétion-Ville. In retrospect, Chedeline wishes her parents understood the importance of breaking from this expected norm through education. People seemed to be discontented by the constant challenges they face in rural areas and, in response, seek means of escaping existing conditions through pathways of education and migration to a major city.

However, Kervens, a college student from Terre Froide studying political science and education in the capital observes large differences in the values held between urban and rural areas. Living in Port-au-Prince, he sees that his peers had a wide variety of dreams and aspirations, whereas in Terre Froide, dreams are more gender-specific: boys aspire to be drivers (stemming from a desired social mobility beyond less glorified agricultural work) while girls follow a defined path of having a family.

When people in both rural and urban communities face adversity, they have looked towards means of sustainability to support their aspirations, particularly in independently shaping their own future rather than relying on outsiders. It has become a consensus that education can provide not only a better standard of living and opportunities but also a more self-reliant future for Haitians as a collective. However, while people in both urban and rural communities have agreed on the importance of education, its effects vary between communities. We hypothesise that this difference of values observed by Kervens stems from the access of opportunities where people within rural communities have not yet understood the possibilities of education and opportunities limited by their communities. Unless someone has gone beyond their community, like Kervens and Chedeline, they are unable to recognise the possibilities beyond the truck drivers passing by their communities.

\section{Education: A curse and a blessing}

In Haiti, individuals have contrasting views on education depending on their involvement with the system. Emmanuel and Chedeline think that education has improved since their educational years, whereas Kervens and Robenson believe that education is continually worsening Haiti's situation, despite the improvement in quality. Both Kervens and Robenson believe that the impacts of education cannot be felt by the Haitian community, as those who have graduated from Haitian universities often leave the country in search of a better life. 
Robenson attributes this phenomenon to the idea of self-interest as a protective mechanism, still existing after a major disaster in Haiti. In Robenson's view, this reflex to care solely for individual shapes a social phenomenon manifested in competition and distrust, even after a disaster has passed. These sentiments, although compounded by natural disasters and recent crises, have historical roots in communal distrust during colonisation and dictatorship. Robenson supposes Haitians have adopted a headstrong, distrustful mentality to protect themselves from further exploitation. While this mentality is understandable and useful in times of extenuating circumstances, it prevents negotiation and understanding between groups. It also accentuates the underlying circumstantial rifts that continually influence meaningful partnerships between Haitians and aid organisations.

In the end, when asked what it meant to be Haitian, most interviewees responded with some paradoxical combination of resilience, perseverance, individuality and community.

\section{Limitations}

Although this ethnography provides insights of the effects into foreign aid on Haitian life, its interview sample size remains limited. Interview participants were additionally recruited through Haiti Hands On's network in their partner communities. Due to these factors, observations made in both rural and urban communities may thus be unrepresentative of the status quo. Observations made during participant observation in these communities in Haiti may also be biased, given the research team being foreigners, despite speaking fluent Creole. We have attempted to account for these potential limitations by recruiting interviewees in communities that have a longstanding and trusting relationship with Haiti Hands On as it allowed for a more candid dialogue about foreign intervention with the interviewers, despite their own positionality. That being said, the circulation of narratives involving suffering beyond fellow Haitians can cause areas of bias and misrepresentation beyond groups represented by our interviewees.

\section{Conclusion}

While this ethnography has corroborated the predominant research on the inefficiencies of international organisations in Haiti, little to no scholarly work had been done to seek out the voices of Haitians a decade after Haiti's devastating earthquake of 2010. This ethnography highlights the voices underpinning the deep- 
seated desires of Haitians to be independent of foreign aid and the strong resilience of Haitians for family and community.

Haiti has a rich history that portrays strength in the face of all kinds of adversity, although this narrative is often excluded from mainstream accounts of the country. Instead, Haiti is portrayed as a country rampant with people unable to help themselves. This has shaped a donor culture that further perpetuates a superficial interpretation of impact within aid organisations. In turn, this image has trickled down to affect the Haitians that aid organisations are serving, resulting in an inefficient use of aid, preservation of exploitative power dynamics and change in attitude towards foreigners. This reality further perpetuates a continued influx of aid that has been present in Haiti for over a decade. Particularly given the growing global instability a decade after the 2010 earthquake, there is an increased need for effective development. By redirecting aid efforts and placing Haitian voices at the centre of their approach, Haiti may finally independently and sustainably tackle its challenges in the next decade.

\section{Appendix}

\section{Interview questions}

1. How long have you lived in (location)?

2. Describe your family.

3. What is your job? What do you work for?

4. How is your lifestyle in (location)?

5 . What types of government support are available in your area?

6. How easy is it to get access to government support within your area?

7. How did the most recent hurricane impact you or your area?

8. Have you had any contact with NGOs, or did it require you to leave (location)? How is the city different from (location)?

9. Are there any NGOs that work in (location) and how is your experience with them?

10. Have you spent much time outside (location)?

11. What do you think about the Pétion-Ville (rich area of Haiti)? Have you been there?

12. How optimistic are you about the new UN mission, MINUJUSTH?

13. What political, economic and other changes have you noticed in recent years? 
Reinvention: an International Journal of Undergraduate Research 14:1 (2021)

14. How does the education you received compare to the ones your children receive now?

15. What does it mean to be Haitian?

1. What qualities would you associate with being Haitian?

2. Who do you find as an inspirational figure?

3. What is your favourite part of being Haitian?

\section{References}

Beeton, D. (2012), 'Soldiers without a cause: Why are thousands of UN troops still in Haiti?', NACLA Report on the Americas, 45 (1), 6-11

Birrell, I. (2012), 'Disastrous relief for Haiti', The Guardian, available at https://www.theguardian.com/commentisfree/2012/dec/30/disastrous-relief-forhaiti?INTCMP=SRCH, accessed June 5, 2020

Chin, C. S., J. Sorenson, J. B. Harris, W. P. Robins, R. C. Charles, R. R. Jean-Charles, J. Bullard, D. R. Webster, A. Kasarskis, P. Peluso, E. E. Paxinos, Y. Yamaichi, S. B. Calderwood, J. J. Mekalanos, E. E. Schadt and M. K. Waldor (2011), 'The origin of the Haitian cholera outbreak strain', New England Journal of Medicine, 364 (1), 3342

Congressional Research Service (2020), 'Haiti’s political and economic conditions', CRS Report, available at https://fas.org/sgp/crs/row/R45034.pdf, accessed 12 September 2020

Edmonds, K. (2013), 'Beyond good intentions: The structural limitations of NGOs in Haiti', Critical Sociology, 39 (3), 1-14

Farmer, P. (2011), Haiti after the earthquake. New York: PublicAffairs

James, E. C. (2010), 'Ruptures, rights, and repair: The political economy of trauma in Haiti', Social Science \& Medicine, 70, 106-13

Justesen, M. and D. Verner (2007), 'Factors impacting youth development in Haiti', World Bank Policy Research Working Paper 4110

Kushner, J. (2012), 'Haitian farmers call on US to stop subsidizing its own', Public Radio International, available at https://www.pri.org/stories/2012-04-12/haitianfarmers-call-us-stop-subsidizing-its-own, accessed March 22, 2018 
Reinvention: an International Journal of Undergraduate Research 14:1 (2021)

Laillet, V. (2020), 'Haiti 10 years later: What happened to the billions pledged to help the people of Haiti?' Global News, available at https://globalnews.ca/news/6421625/haiti-10-years-later-billions-pledged/, accessed 5 June 2020

Marcelin, L. H. (2015), 'Violence, human insecurity, and the challenge of rebuilding Haiti', Current Anthropology, 56 (2), 230-55

Moreno, M. F., C. C. V. Barga and M. S. Gomes (2012), 'Trapped between many worlds: A postcolonial perspective on the UN mission in Haiti (MINUSTAH)', International Peacekeeping, 19 (3), 377-92

Panchang, P. (2016), Haiti: Contesting the UN occupation, NACLA Report on the Americas, 43 (6): 5-6

Pilinger, M., I. Hurd and M. N. Barnett (2016), 'How to get away with cholera: The UN, Haiti, and International Law', American Political Science Association, 14 (1), 70-86

The Lancet (2006), 'UN Peacekeepers in Haiti', The Lancet Editorial, 816

The Lancet (2016), 'The UN in Haiti: An adulterated vision of accountability', The Lancet Editorial, 4, 872

The World Bank (2017), 'Improving access to education for the poor in Haiti', World Bank Projects and Operations, available at https://www.worldbank.org/en/results/2017/04/11/improving-access-to-educationfor-the-poor-in-haiti, accessed May 30, 2020

UN Peacekeeping (2018), 'MINUSTAH fact sheet', United Nations, available at https://peacekeeping.un.org/en/mission/minustah, accessed February 27, 2018

United Nations Security Council (2017), 'General Assembly approves appropriation of \$6.8 Billion for 14 peacekeeping operations in 2017/18', United Nations, available at https://www.un.org/press/en/2017/ga11927.doc.htm, accessed June 13, 2020

United Nations Security Council (2018), 'New mission in Haiti preparing transition from peacekeeping to development role, Under-Secretary-General tells Security Council ahead of mandate renewal', United Nations, available at https://www.un.org/press/en/2018/sc13274.doc.htm, accessed June 5, 2020 
To cite this paper please use the following details: Tse et al. (2021), 'Haiti: An Ethnographic Study of the Effects of International Aid on Haitian Life', Reinvention: an International Journal of Undergraduate Research, Volume 14, Issue 1, https://reinventionjournal.org/article/view/657. Date accessed [insert date]. If you cite this article or use it in any teaching or other related activities please let us know by emailing us at Reinventionjournal@warwick.ac.uk. 